\title{
PENGGUNAAN BAHASA INDONESIA DIALEK MAKASSAR DALAM KEGIATAN PEMBELAJARAN DI SMA NEGERI 6 MAROS: KAJIAN SOSIOLINGUISTIK
}

\author{
${ }^{1}$ Mutmainnah, ${ }^{2}$ Ery, ${ }^{3}$ Munira \\ ${ }^{1}$ Program Studi Bahasa Indonesia, Fakultas Ilmu Budaya, Universitas Hasanuddin, Makassar \\ ff.mutmainnah@gmail.com \\ ery.iswari@gmail.com \\ munirahasjim@unhas.ac.id
}

\begin{abstract}
The research aimed to describe the forms of the code mixing, code switching, and interference at SMA Negeri 6 Maros, Bontoa District, Maros Regency, Sulawesi Selatan. This was a qualitative descriptive research examining linguistic phenomena with the sociolinguistic approach. Data resource were the speeches used by the teachers of the study programs of Religious Education, Biology, History Science, Sport Education, Indonesian Language, Education of Art and Culture, Mathematics and all the speeches of the students involving in the learning process which contained the code mixing, code switching, and interference. Data were collected by the non-participative observation. While the data were also collected by the scrutinized technique of the free involving conversation, recording technique, and note-taking. The classified data were then analysed by the qualitative descriptive analysis method.

The research result indicates that the code mixing forms are: verb, adverb, conjunction, reduplication, personal pronouns, and phrases, whereas the code switching is in the forms of independent clauses, coordinative clauses, and sentences. and the interferences are: the addition of klitika mi, pi, ji, phoneme removal, added phonemes, phoneme replacement /i/ being /e/ and phoneme $/ \mathrm{u} /$ being $/ \mathrm{o} /$. The code mixing, code switching, and interference occur in the learning process at SMA Negeri 6 Maros, Bontoa District, Maros Regency, Sulawesi Selatan. performed by the teachers, students from Indonesian language into Makassar dialect .
\end{abstract}

Key-words: Code mixing, code switching, interference

\section{PENDAHULUAN}

Manusia sebagai makhluk individu dan makhluk sosial memiliki keinginan untuk selalu berkomunikasi dan bekerja sama antara sesamanya dengan menggunakan bahasa. Ketika berinteraksi antara pengguna bahasa yang satu dengan pengguna bahasa yang lain, akan timbul suatu kontak bahasa. Dengan bahasa, seseorang akan memiliki berbagai informasi dan ilmu pengetahuan.

Fenomena kebahasaan dapat terjadi karena adanya kontak bahasa, khususnya di daerah perbatasan yang berbatas dengan yang berbeda kabupaten dan suku. Pengaruh pemakaian bahasa (bahasa ibu) dalam melakukan kontak bahasa dapat menentukan keberlangsungan bahasa yang digunakan oleh dua suku atau etnis. Situasi kebahasaan ini menggambarkan bahwa telah terjadi kontak bahasa antara bahasa ibu dan bahasa dari etnis lainnya. Peristiwa kontak bahasa yang terjadi pada masyarakat bilingual dapat menjadi objek kajian sosiolinguistik. Sumarsono dan Patana (2004) mendefinisikan sosiolinguistik sebagai ilmu linguistik institusional yang berkaitan dengan pertautan bahasa dengan orang-orang yang memakai bahasa itu. Dalam ilmu sosiolinguistik dibicarakan bagaimana penutur bahasa menggunakan bahasa yang bervariasi dari sejumlah ragam bahasa yang digunakan oleh masyarakat sehingga 


\section{1 | JURNAL ILMU BUDAYA}

memicu terjadinya alih kode (code switching), campur kode (code mixing), dan interferensi (interference).

$$
\text { Rahardi (2001) mengatakan }
$$

campur kode adalah suatu keadaan berbahasa lain bilamana orang mencampur dua atau lebih bahasa atau ragam bahasa dalam suatu tindak bahasa tanpa ada sesuatu yang menuntut percampuran bahasa itu. Lebih lanjut Kridalaksana (2009) menyatakan bahwa campur kode merupakan penggunaan satuan bahasa dari satu bahasa ke bahasa lain untuk memperluas gaya bahasa tersebut.

Menurut Chaer (2004), alih kode adalah gejala peralihan pemakaian bahasa karena berubahnya situasi sedangkan Hymes (dalam Chaer, 2004) mengatakan alih kode itu bukan hanya terjadi antarbahasa, tetapi juga terjadi antarragam atau gaya bahasa. Lebih lanjut Taha (2008) menambahkan bahwa alih kode antarbahasa dapat terjadi pada penutur yang menguasai dua bahasa atau lebih sedangkan alih kode antarvariasi dapat terjadi pada penutur dwidialek.

Alwasilah (2005) mengatakan bahwa interferensi adalah kekeliruan yang disebabkan oleh adanya kecenderungan membiasakan pengucapan (ujaran) suatu bahasa terhadap bahasa lain mencakup pengucapan satuan bunyi, tata bahasa, dan kosakata. Interferensi merupakan kekeliruan yang terjadi sebagai akibat terbawanya kebiasaan-kebiasaan ujaran bahasa ibu ke dalam bahasa kedua. Dari segi kebahasaan, interferensi dibagi menjadi dua, yakni interferensi bentuk dan interferensi bahasa. Menurut Poedjosoedarmo (2006) "interferensi bentuk meliputi unsur bahasa dan variasi bahasa, sedangkan interferensi bahasa meliputi interferensi fonologis, leksikal. morfologis, sintaksis, dan semantik."

Merujuk pada UU No. 24 tahun 2009 Bab III yang menjelaskan bahwa Bahasa Indonesia sebagai bahasa resmi negara sebagaimana dimaksud pada ayat (1) berfungsi sebagai bahasa resmi kenegaraan, pengantar pendidikan, komunikasi tingkat nasional, pengembangan kebudayaan nasional, transaksi dan dokumentasi niaga, serta sarana pengembangan dan pemanfaatan ilmu pengetahuan, teknologi, seni, dan bahasa media massa, sehingga bahasa Indonesia ini wajib digunakan dalam kegiatan dan kenegaraan termasuk dalam aktivitas pembelajaran. Namun, fenomena yang berkembang saat ini berdasarkan hasil penelitian ditemukan masih banyak guru dan siswa tidak menggunakan bahasa Indonesia ragam formal dalam kegiatan pembelajaran.

Bahasa formal dalam kegiatan pembelajaran yang dimaksud adalah bahasa Indonesia yang tidak mencampurkan antara bahasa Indonesia dan bahasa ibu. Di kalangan guru dan siswa, interaksi yang terjadi antara guru dan siswa dalam pembelajaran sebaiknya menggunakan bahasa Indonesia sesuai UU yang telah disebutkan di atas. Meskipun demikian, di dalam interaksi sosial pengguna bahasa cenderung melibatkan keanekaragaman bahasa yang mengakibatkan adanya pemilihan bahasa. Proses menentukan pilihan bahasa mana yang digunakan pada peristiwa komunikasi tidak selalu mencapai kesepakatan. Kadang kedua pengguna bahasa mempertahankan masing-masing bahasa yang digunakan, yang paling penting bahasa tersebut dapat dipahami dan dimengerti oleh mereka.

Seperti halnya yang terjadi di SMA Negeri 6 Maros yang bertempat di Kecamatan Bontoa, Kabupaten Maros, yakni sebelah Selatan yang berbatasan dengan Kota Makassar dan sebelah Utara berbatasan dengan Kabupaten Pangkep hingga saat ini penduduk Kecamatan Bontoa, Kabupaten Maros umumnya adalah pengajar dan pembelajar di SMA Negeri 6 Maros. Mereka mengggunakan dua bahasa daerah, yakni bahasa Makassar dan Bugis. Kedua bahasa daerah tersebut mempengaruhi pengguna bahasa ketika 


\section{2 | JURNAL ILMU BUDAYA}

Volume 6, Nomor 2 Desember 2018

berbahasa Indonesia sehingga menimbulkan bahasa Indonesia dialek Makassar dan dialek Bugis.

Dengan demikian, Bahasa Indonesia dialek Makassar atau yang dikenal dengan Logat Makassar adalah salah satu bentuk bahasa yang dimasukkan dalam kelompok Trade Malay (Melayu Pasar). Bahasa ini biasanya digunakan sebagai bahasa perdagangan di lingkungan Makassar, Sulawesi Selatan. Jumlah penutur bahasa ini mencapai 1.889 .000 jiwa pada tahun 2000 dan diperkirakan jumlah penutur bahasa ini terus bertambah sampai mencapai \pm 3.500 .000 jiwa. Bahasa ini kebanyakan digunakan oleh pendatang dari luar Kota Makassar, penduduk Kota Makassar, kalangan remaja, atau orang Makassar yang tidak pandai berbahasa daerah Makassar. Penggunaan bahasa Indonesia dialek Makassar menggunakan ciri khas yang menggunakan klitik $-m i$, $-p i$, $-j i,-m o,-k i$, -ta', -ji, -jeko, -meko, -ko, dan na-suara yang halus. Pada bahasa ini, banyak kata yang mempunyai dua arti sama pada satu kalimat, misalnya "Na'ambil $\boldsymbol{k i}$ itu tadi' bukuku" (Dia ambil (dia) itu tadi buku saya),yang artinya dia mengambil tadi buku saya. Contoh lainnya seperti "Begitu mi padeng" yang artinya "Begitu saja, jika begitu". (https: //id.Wikipedia.org/wiki/logat_Makassar).

Menurut Taha (2008:61), sesuai dengan tujuan pengajaran Bahasa Indonesia dan sesuai pula dengan pokokpokok kebijaksanaan pendidikan dan kebudayaan dalam Garis-garis Besar Haluan Negara, fungsi bahasa Indonesia dalam hubungannya dengan pendidikan nasional ialah (1) sebagai mata pelajaran dasar pokok, (2) sebagai bahasa pengantar pada semua jenis dan jenjang lembaga pendidikan, (3) sebagai bahasa penalaran, (4) sebagai bahasa pengembagan diri hasil pendidikan. Hal tersebut menandakan bahwa seorang guru ketika berada dalam kelas dituntut untuk menggunakan bahasa Indonesia dengan baik dan benar.
Aktivitas pembelajaran di SMA Negeri 6 Maros, Kecamatan Bontoa, Kabupaten Maros ketika berbahasa Indonesia sebagaimana yang telah dijelaskan sebelumnya sering mengalami masalah dalam berbahasa Indonesia. Permasalahan ini terjadi baik guru maupun siswa masih menggunakan bahasa Indonesia dialek Makassar. Saat proses pembelajaran, mereka melakukan campur kode, alih kode, dan interferensi. Bahasa yang sering digunakan dalam berinteraksi di dalam kelas adalah bahasa Indonesia dialek Makassar. Pada saat proses pembelajaran guru dan siswa sering menggunakan bahasa Indonesia dialek Makassar. Sementara yang dapat menjelaskan alasan guru dan siswa menggunakan campur kode, alih kode, dan interferensi dalam proses pembelajaran karena guru dan siswa memiliki latar belakang yang sama, yakni mereka memiliki kesamaan suku.

Bentuk-bentuk penggunaan bahasa yang berupa campur kode, alih kode, dan interferensi digunakan oleh guru dan siswa karena adanya alasan tertentu. Seperti saat menjelaskan kembali atau mengulang kembali materi yang sudah dijelaskan sehingga siswa mampu memahami maksud yang diutarakan oleh guru dengan lebih baik dan dapat menangkap materi secara jelas. Supaya terlihat akrab sehingga siswa tidak takut atau ragu-ragu ketika menyampaikan suatu pertanyaan atau pendapatnya.

Berikut contoh-contoh yang menunjukkan fenomena bentuk penggunaan bahasa yang berupa campur kode, alih kode, dan interferensi yang terjadi dalam proses pembelajaran di SMA Negeri 6 Maros, Kecamatan Bontoa, Kabupaten Maros, Sulawesi Selatan.

Guru : Bagaimana PR minggu lalu, kalian sudah kerjakan?

Siswa : Sudah Bu.

Guru : Baiklah kalau begitu. ...Ibu suruh kalian kerja baji-baji itu $\operatorname{Pr}$ supaya nupahang $k i$ itu ide pokok. 


\section{3 | JURNAL ILMU BUDAYA}

(Baiklah kalau begitu... Ibu menyuruh kalian mengerjakan PR dengan benar supaya kamu mengerti tentang ide pokok).

Guru : Siapa yang tidak hadir hari ini?

Siswa : Irwansyah, Bu

Guru : Angngapai seng, Irwansyah (Kenapa lagi, Irwansyah)

Siswa : Na antar ki bedeng pergi berobat mama na ka garring ki, Bu (Dia mengantar katanya pergi berobat ibunya karena ibunya sakit, Bu)

(Dia mengantar ibunya pergi berobat karena sakit, $\mathrm{Bu}$ )

Guru : Oh, selain Irwansyah siapa lagi yang tidak hadir

Siswa : Tidak ada mi, Bu. Hadir semua ji

Pada contoh di atas guru memulai proses pembelajaran dengan menggunakan campur kode dialek Makassar dengan mengatakan: "Baiklah kalau begitu. Ibu suruh kalian mengerjakan PR baji'-baji' (dengan benar) supaya nu pahangki (kamu mengerti) itu ide pokok.". Bentuk campur kode yang digunakan dalam tuturan guru tersebut berwujud kata ganti orang dan kata ulang (reduplikasi), yaitu nu ( kamu), baji'-baji' (dengan benar) serta kata pahang ki (mengerti) adalah bentuk interferensi bahasa Makassar, yakni pahangngi. Setelah itu guru ingin mengetahui keadaan siswanya dengan mengatakan "Siapa yang tidak hadir hari ini?" lalu siswa pun menjawab “ Irwansyah, Bu". Setelah itu guru kembali bertanya dengan menggunakan alih kode, yakni "Angngapai seng, Irwansyah" (kenapa lagi) Irwansyah". Selanjutnya tuturan siswa saat menjawab menggunakan campur kode, yakni "Na antar $k i$ bedeng pergi berobat mama na ka garring ki, Bu" (Dia mengantar ibunya pergi berobat karena sakit, Bu). Bentuk campur kode dalam tuturan siswa berwujud persona orang ketiga (na), kata fatis (bedeng) dan verba (garring). Selanjutnya pada tuturan guru yang bertanya kembali, yakni "Siapa lagi yang tidak hadir" lalu siswa menjawab "Tidak ada mi, Bu. Hadir semua jï. Tuturan tersebut menggunakan interferensi morfologi bahasa Indonesia ke dialek Makassar, yakni klitika $\boldsymbol{m i}$ dan $\boldsymbol{j i}$ yang melekat pada kosakata bahasa Indonesia. Klitika $\boldsymbol{m i}$ dan $\boldsymbol{j i}$ dalam bahasa Makassar dapat berarti sebagai penekanan.

Guru dan siswa menggunakan campur kode, alih kode, dan interferensi dalam tuturannya disebabkan oleh faktor kebiasaan menggunakan dialek Makassar saat berada di rumah, guru mengimbangi kemampuan berbahasa siswa dan pengaruh bahasa pertama. Guru dan siswa tinggal dan bermukim di tempat yang sama dan menggunakan dialek bahasa yang sama saat berada di rumah, yaitu dialek Makassar.

Berdasarkan latar belakang tersebut, penggunaan campur kode, alih kode, dan interferensi dalam proses pembelajaran di SMA Negeri 6 Maros, Kecamatan Bontoa, Kabupaten Maros, Sulawesi Selatan, menarik dan perlu diteliti. Hal tersebut disebabkan campur kode, alih kode, dan interferensi, sering dijadikan metode atau strategi dalam proses pembelajaran sehingga dapat berakibat tidak akan tercapai tujuan pemakaian bahasa Indonesia yang baku, cermat, tepat, dan efesien dalam komunikasi serta tidak sesuai dengan amanat Undang-Undang No. 24 tahun 2009 Bab III yang menjelaskan bahwa Bahasa Indonesia sebagai bahasa resmi negara yang berfungsi sebagai bahasa pengantar pendidikan. Pemakaian bahasa Indonesia dengan baik dan benar yang mengandung makna baik bila sesuai dengan konteks situasi pemakaiannya dan benar bila mengikuti kaidah bahasa Indonesia baku.

\section{METODE PENELITIAN Jenis Penelitian}

Penelitian ini merupakan jenis penelitian kualitatif dengan menggunakan metode deskriptif yang selanjutnya disebut 


\section{4 | JURNAL ILMU BUDAYA}

dengan penelitian deskriptif kualitatif. Penelitian deskriptif kualitatif, yakni menjelaskan data-data sesuai dengan keadaan data yang sebenarnya. Menurut Moleong (2009), metode kualitatif sebagai prosedur penelitian yang menghasilkan data deskriptif berupa kata-kata tertulis atau lisan dari orang-orang yang diamati. Dengan demikian, pendeskripsian data ini berupa tuturan guru dan siswa dalam proses pembelajaran yang menggunakan bahasa Indoensia dialek Makassar.

\section{Sumber Data}

Sumber data penelitian ini, yaitu tuturan guru yang bersuku Makassar pada mata pelajaran Pendidikan Agama, Biologi, Sejarah, Penjas, Bahasa Indonesia, Seni Budaya, dan Matematika di SMA Negeri 6 Maros yang berjumlah sembilan orang bersama semua siswa kelas $\mathrm{X}, \mathrm{XI}$, dan XII yang terlibat dalam proses pembelajaran atau sebaliknya.

\section{Populasi dan Sampel}

Populasi data penelitian ini adalah keseluruhan tuturan guru yang bersuku Makassar pada mata pelajaran Pendidikan Agama, Biologi, Sejarah, Penjas, Bahasa Indonesia, Seni Budaya, dan Matematika di SMA Negeri 6 Maros berjumlah sembilan orang serta semua siswa yang terlibat dalam proses pembelajaran di SMAN 6 Bontoa, Kecamatan Bontoa, Kabupaten Maros, Sulawesi Selatan. Adapun rincian setiap kelas terdiri atas kelas X1, X2, X3, berjumlah 105 siswa, kelas XI IPA1, XI IPA2, XI IPA3, XI IPS1, XI IPS2 berjumlah 150 siswa, dan kelas XII IPA1, XII IPA2, XII IPA3, XII IPS1, XII IPS2 berjumlah 145 siswa. Jadi, keseluruhan siswa di SMAN 6 Bontoa, Kecamatan Bontoa, Kabupaten Maros, Sulawesi Selatan berjumlah 400 siswa. Sampel yang digunakan dalam penelitian ini adalah sebagian dari keseluruhan tuturan yang mengandung campur kode, alih kode, dan interferensi, yang dituturkan oleh guru yang bersuku Makassar dan siswa dalam proses pembelajaran.

\section{Metode Pengumpulan Data}

Pengumpulan data dilakukan dengan metode simak bebas libat cakap, perekaman, dan pencatatan. Metode simak libat cakap, peneliti hanya berperan sebagai pengamat bahasa kepada para informan dalam hal ini guru dan siswa. Teknik rekam dilakukan saat proses pembelajaran dengan menggunakan Tape Recoeder. Teknik catat dilakukan setelah teknik perekaman. Semua data yang direkam kemudian dicatat selanjutnya diketik dengan menggunakan komputer.

\section{Metode Analisis Data}

Data yang diperoleh melalui metode simak, teknik rekam, dan catat selanjutnya dianalisis dengan mengklasifikasi dan mengelompokkan. Dalam pengelompokan digunakan langkah-langkah, yakni 1. Identifikasi Data. Semua tuturan guru yang bersuku Makassar dan siswa dalam proses pembelajaran pada mata pelajaran Pendidikan Agama, Biologi, sejarah, Penjas, Bahasa Indonesia,Seni Budaya, dan Matematika, 2. Klasifikasi Data. Data lalu diklasifikasikan berdasarkan bentukbentuk campur kode, alih kode, dan interferensi 3. Analisis Data. Data dianalisis secara kontekstual berdasarkan peristiwa tutur yang terjadi ketika proses pembelajaran.

\section{PEMBAHASAN}

Penelitian ini secara umum berkaitan dengan aspek kebahasaan yang terjadi dalam proses pembelajaran di SMA Negeri 6 Maros, Kecamatan Bontoa, Kabupaten Maros, Sulawesi Selatan, dan aspek-aspek teoretis yang menjadi unsur penting yang menyebabkan tetap digunakannya alih kode, campur kode dan interferensi ketika proses pembelajaran.

Hasil penelitian ini mengungkapkan bahwa bentuk-bentuk campur kode yang berwujud verba, adverbia, konjungsi, kata ulang, kata ganti orang, dan frasa, alih kode berwujud klausa mandiri, klausa koordinatif, dan kalimat, sedangkan 


\section{5 | JURNAL ILMU BUDAYA}

interferensi berwujud penambahan klitika $m i, \quad p i, \quad j i$, penghilangan fonem, penambahan fonem, dan penggantian fonem /i/ menjadi /e/ dan fonem /u/ menjadi /o/.

Data campur kode, alih kode, dan inteferensi berjumlah 80 data sedangkan data yang dianalisis berjumlah 49, dari total 28 kali pertemuan. Data tersebut diperoleh dari mata pelajaran Bahasa Indonesia 4 kali pertemuan, Pendidikan Agama 4 kali pertemuan, Matematika 4 kali pertemuan, Penjas 4 kali pertemuan, Biologi 4 kali pertemuan, Seni Budaya 4 kali pertemuan, Sejarah 4 kali pertemuan Setiap pertemuan selama 2 x 45 menit, sehingga keseluruhan waktu yang digunakan untuk penelitian ini 2520 menit.

Penggunaan campur kode, alih kode, dan interferensi yang sering digunakan dalam proses pembelajaran menyebabkan pengaruh positif dan negatif. Pengaruh positifnya, yaitu siswa lebih paham dengan maksud yang disampaikan oleh guru sehingga proses pembelajaran dapat berlangsung dengan lancar. Pengaruh negatif dari penggunaan campur kode, alih kode, dan interferensi tersebut dapat mengganggu tujuan pembelajaran terutama yang berkaitan dengan perolehan keterampilan berbahasa Indonesia terhadap siswa, yakni

1. Siswa kurang mampu memahami sehingga tidak bisa membedakan ketika menggunakan bahasa Indonesia di dalam kelas maupun di luar kelas, dengan kata lain siswa tidak mengerti perbedaan antara menggunakan bahasa Indonesia di tempat yang formal dan tidak formal

2. Rendahnya penguasaan bahasa Indonesia atau kosakata para peserta didik atau siswa. Dengan demikian tidak akan tercapai tujuan pemakaian bahasa Indonesia yang baku, cermat, tepat, dan efisien dalam komunikasi, yaitu pemakaian bahasa Indonesia yang baik atau benar yang mengandung makna baik bila sesuai dengan konteks situasi pemakaiannya dan benar bila mengikuti kaidah.

Masyarakat di Kecamatan Bontoa merupakan masyarakat multilingual, sehingga mereka menggunakan dua bahasa atau lebih. Selain bahasa Indonesia mereka juga menggunakan bahasa Makassar dan bahasa Bugis dalam berkomunikasi seharihari.

Penelitian ini menemukan penggunaan bentuk campur kode, alih kode, dan interferensi dalam proses pembelajaran bahasa Indonesia di SMA Negeri 6 Maros, Kabupaten Maros baik guru maupun siswa masih menggunakan dua bahasa (Indonesia dan Makassar) sebagai alat komunikasi dalam situasi formal.

Kegiatan pembelajaran bahasa Indonesia di SMA Negeri 6 Maros, Kabupaten Maros, guru menggunakan bahasa Indonesia sebagai alat tutur namun seringkali beralih dan bercampur ke dalam bahasa Makassar ataupun sebaliknya. Hal ini disebabkan karena faktor kebiasaan. Oleh sebab itu, ketika proses pembelajaran berlangsung guru menggunakan bahasa Indonesia dan bahasa Makassar sehingga terjadi campur kode. alih kode, dan interferensi. Adapun bentuk-bentuk campur kode, alih kode, dan interferensi akan dipaparkan di bawah ini:

\section{Bentuk campur kode berwujud verba} Contoh (1)

Guru : Kalian masih inga' pelajaran kelas $\mathrm{X}$ tentang tumbuhan dikotil dan monokotil ?

Siswa : Masih di inga' sedikit, Bu

Dalam tuturan contoh (1) ketika proses pembelajaran terjadi campur kode yang dilakukan oleh siswa. Penggunaan campur kode dari bahasa Indonesia ke dialek Makassar tidak ada unsur kesengajaan tetapi unsur kebiasaan siswa ketika mengucapkan kata ingat menjadi "inga". Hal tersebut dipengaruhi oleh 
kebiasaaa siswa menggunakan bahasa Makassar.

\section{Bentuk campur kode berwujud adverbia}

\begin{tabular}{|c|c|c|}
\hline \multicolumn{3}{|c|}{ Contoh (2) } \\
\hline Guru 1 & : & $\begin{array}{l}\text { Pak, permisi dulu mau } \\
\text { memanggil Andri } \\
\text { sebentar }\end{array}$ \\
\hline Guru 2 & : & $\begin{array}{l}\text { Andri, dipanggil Pak } \\
\text { Amir }\end{array}$ \\
\hline Siswa & . & $\begin{array}{l}\text { Iye Pak. } \\
\text { rolong, Pak }\end{array}$ \\
\hline
\end{tabular}

Penggunaan campur kode bahasa Indonesia ke dialek Makassar dalam proses pembelajaran yang terdapat dalam contoh (2) berupa kata yakni kata "rolong" yang artinya dulu. Penggunaan kata "rolong" umumnya digunakan oleh penutur suku Makassar sebagai kata penegas. dalam percakapan.

3. Bentuk campur kode berwujud konjungsi

Contoh (3)

Guru : Hari ini kalian tidak belajar karena ada rapat guru

Siswa : Rapat ki seng guru, Bu ?

Berdasarkan contoh (3), peristiwa campur kode berupa kata konjungsi ditandai dengan penggunaan kata "seng" yang artinya lagi. Dalam proses pembelajaaran siswa bertanya dengan menggunakan bahasa Indonesia yang bercampur kode ke dialek Makassar. Penggunaan campur kode yang berwujud kata "seng" dilakukan secara reflek.

\section{Bentuk campur kode berwujud kata ulang}

Contoh (4)

Guru : Kalian sebentar lagi akan Ujian Nasional. Jadi, appilajara ko baji'-baji'.

Siswa : Iye, Bu

Peristiwa campur kode pada contoh (4) berwujud kata ulang atau reduplikasi. Guru menggunakan tuturan dari bahasa Indonesia ke dialek Makassar berupa kata ulang yaitu 'baji'-baji' yang artinya baik-baik. Campur kode tersebut terjadi saat guru akan menutup pelajaran hari itu dengan memberikan nasihat kepada siswa kelas XII agar lebih giat belajar untuk menghadapi Ujian nasional. Penggunaan campur kode yang berupa kata ulang :baji'-baji'" artinya baik-baik untuk menjalin keakraban antara guru dan siswa.

\section{Bentuk campur kode berwujud kata ganti orang}

Contoh (5)

Siswa 1 : Kita kerjakan $k i$ dulu tugas yang diberikan Ibu. Kau mo yang cari ki jawabang na, nakke pa yang menulis.

Siswa 2 : Yang penting baji' ji tulisang nu

Tuturan dalam contoh (5) terjadi campur kode dari bahasa Indonesia ke dialek Makassar yang berwujud kata ganti orang pertama tunggal yaitu "nakke" yang artinya saya. dan kata ganti orang kedua tunggal yaitu " $\boldsymbol{n u}$ ” yang artinya kamu, Pengguanaan campur kode yang berwujud kata ganti orang pertama tunggal dan kedua tunggal tersebut dituturkan oleh dua orang siswa ketika mengerjakan tugas yang diberikan oleh guru dalam pelajaran Bahasa Indonesia.

\section{Bentuk campur kode berwujud frasa} Contoh (6)

Guru : Sebuah karya sastra itu ada kelebihan dan kekurangannya.

Misalnya kalau kalian membaca novel Sitti Nurbaya, ada kelebihannya ada juga kekurangannya. Mungkin dari segi bahasa na niya tena $\mathbf{n u}$ pahangngi.

Siswa : Iye, $\mathrm{Bu}$.

Pada contoh (6) terjadi peristiwa campur kode dari bahasa Indonesia ke dialek Makassar berbentuk frasa. Penggunaan frasa tersebut digunakan guru saat menjelaskan materi pelajaran. Frasa 


\section{7 | JURNAL ILMU BUDAYA}

Volume 6, Nomor 2 Desember 2018

"niya tena nu pahangngi." yang artinya kamu tidak mengerti dituturkan guru saat proses pembelajaran di kelas.

7. Bentuk alih kode berwujud klausa mandiri

Contoh (7)

Guru : Angngalle ko rolong sapidol

Siswa : Iye, $\mathrm{Bu}$

Pada contoh (7) terjadi peristiwa alih kode yang berupa klausa mandiri dari dialek Makassar yaitu "Angngalle ko rolong sapidol" artinya kamu pergi dulu mengambil spidol. Guru menyuruh kepada siswa mengambil spidol pada saat pembelajaran karena saat itu di ruang kelas tersebut tidak memiliki spidol. Supaya tuturannya mudah dipahami oleh siswa, maka guru beralih kode ke dialek Makassar yang menjadi bahasa sehari-hari siswa.

\section{Bentuk alih kode berwujud klausa koordinatif}

Contoh (8)

Guru

Ibu sareang ko tugas nampa nu jamai (memberi kamu tugas lalu kamu kerjakan), dan kenapa (mengapa) buku tugas yang dikumpul hanya ini saja ? (karena hanya ada beberapa buku yang dikumpul di meja guru)

Angkat tangan siapa yang tidak kumpul tugas !

Guru : (Ibu memberikan tugas untuk kalian kerjakan, lalu mengapa buku tugas yang dikumpul hanya ini saja? )(karena hanya ada bebrapa buku yang dikumpul di meja guru)

Siswa : (Hanya ada beberapa siswa yang mengangkat tangannya)

Dalam contoh (8) terdapat peristiwa alih kode yang berwujud alih kode koordinatif. Peristiwa tersebut ditandai dengan dimasukkannya tuturan "sareang ko tugas nampa nu jamai" artinya ibu memberikan tugas lalu kalian kerjakan. Ciri dari klausa koordinatif disini adalah adanya penghubung (konjungsi) yaitu "lalu". Guru sudah memberikan tugas kepada semua siswa beberapa minggu yang lalu namun hanya beberapa orang saja yang sudah mengerjakan tugas. Guru beralih kode dari bahasa Indonesia ke dialek Makassar dalam tuturannya karena memiliki tujuan untuk mempertegas tuturannya supaya mudah dipahami oleh siswa sehingga proses pembelajaran dapat berlangsung dengan baik.

\section{Bentuk alih kode berwujud kalimat} Contoh (9)

Guru : (Sudah menjelaskan panjang lebar tetapi ada

seorang siswa sedang asyik bermain HP) Woe...

apa nu pare angjoeng, erangngi rinni HP nu.

Siswa : (Maju ke depan membawa HPnya lalu menyerahkan ke guru)

Tuturan dalam contoh menunjukkan peristiwa alih kode dalam bentuk kalimat yang dilakukan oleh guru ketika belajar Matematika . Peristiwa alih kode tersebut terjadi saat guru melihat ada siswa yang tidak memperhatikan pelajaran namun asyik memainkan HP.

Guru menggunakan alih kode dialek Makassar tersebut, supaya tuturannya mudah dipahami oleh siswa sehingga proses pembelajaran berlangsung dengan baik. Peristiwa alih kode yang berwujud kalimat yaitu "Woe...apa nu pare angjoeng, erangngi rinni $\mathrm{HP}$ nu" artinya hey... apa yang kau lakukan, bawa ke sini HPти. Tuturan alih kode yang digunakan oleh guru karena kesal kepada siswa yang tidak memperhatikan pelajaran.

10. Bentuk interferensi berwujud penambahan klitika $m i, p i, j i$

Contoh (10)

Siswa : Cepat mi kerja tugasmu. Sudah mau dikumpul

Siswa : Iya tunggu $\boldsymbol{m i}$ hampir $\boldsymbol{m i}$ selesai Pada contoh (10) terjadi proses peminjaman kata dalam bahasa Makassar dengan cara penambahan klitika mi. Klitika mi adalah bentuk peminjaman dari 
bahasa Makassar yang diletakkan pada bunyi akhir pada bahasa donor. Klitika $\boldsymbol{m i}$ pada kata cepat mi, tunggu mi, hampir mi dalam dialek Makassar berfungsi sebagai penekanan.

\section{Bentuk interferensi berwujud penghilangan fonem}

Contoh (11)

Siswa : Tida? pergi ko latihan futsal

Siswa : Bukan pi hari ini. Beso pi

Melihat contoh di atas dapat diketahui bahwa siswa yang berdwibahasa bahasa Makassar ke bahasa Indonesia memilki kecenderungan mengurangi fonem [k] di akhir kata dasar pada waktu berbahasa Indonesia dan fonem [k] dapat juga menjadi glotal [?]. Penggunaan dialek Makassar yang berciri mengurangi fonem [k] di akhir kata dasar memengaruhi penggunaan bahasa Indonesia pada tuturan siswa.

12. Bentuk interferensi berwujud penambahan fonem

Contoh (12)

Guru : Kalian pahang mi cara permainan bola basket .

Siswa : Iye Pak ! Guru memulai proses pembelajaaran dengan menggunakan bahasa Indonesia ragam resmi namun guru tidak menyadari kalau dalam tuturannya tersebut terjadi interferensi dari bahasa Indonesia ke dialek Makassar. Dalam tuturan contoh (12) guru mengatakan kata "Pahang" yang artinya mengerti. Interferensi dilakukan oleh guru ketika proses pembelajaaran akan dimulai. Interferensi dari bahasa Indonesia ke dialek Makassar tersebut untuk menanyakan kepada siswa sebelum memulai pembelajaran hari itu. Adapun guru menggunakan interferensi dari bahasa Indonesia ke dialek Makassar ketika proses pembelajaaran dilakukan secara tidak sadar.

\section{Bentuk interferensi berwujud penggantian fonem /i/ menjadi /e/ dan fonem /u/ menjadi /o/}

Contoh (13)

Siswa (1) : Ambe ki dulu buku paketku

Siswa (2) : Dimana nu simpan ?

Pada contoh di atas, kata ambe digunakan dengan perubahan fonem. Fonem /e/ pada kata ambe seharusnya diisi dengan fonem /i/, tetapi penutur lebih memilih kata ambe daripada ambil dan terjadi pelesapan pada fonem $/ \mathrm{V}$.

Contoh (14)

Siswa (1) : Arya, sama kelompok ki. Tare? kursimu ke sini!

Siswa (2) : Kelompok berapa ki?

Siswa (1) : Kelompok tiga

Pada contoh di atas, fonem /e/ pada kata tare? seharusnya diisi fonem /i/, yaitu tarik tetapi penutur Makassar lebih memilih kata tare? daripada kata tarik. Dalam hal kaidah penulisan bahasa baku kata tersebut dianggap tidak tepat dari segi fonetisnya.

Contoh (15)

Guru : Kenapa Andi tidak ke sekolah?

Siswa : Sakit ki, Bu.

Guru : Sakit apa?

Siswa : Bator-bator ki, Bu.

Pada contoh di atas kata bato?-

bator digunakan dengan perubahan fonem. Fonem /o/ pada kata bator-bato? seharusnya diisi dengan fonem /u/. Penutur Makassar umumnya lebih memilih kata batop-bato? daripada batuk.

\section{SIMPULAN}

Beradasarkan hasil penelitian dan pembahasan, dapat disimpulkan bahwa bentuk-bentuk campur kode dapat berwujud, yaitu (1) verba, (2) adverbia, (3) konjungsi, (4) kata ulang, (5) kata ganti orang, (6) frasa. Adapun bentuk alih kode berwujud, yaitu (1) klausa mandiri, (2) klausa koordinatif, (3) kalimat sedangkan interferensi berwujud, yaitu (1) penambahan klitika mi, pi, ji, (2) penghilangan fonem, (3) penambahan fonem, (4) penggantian fonem /i/ menjadi /e/ dan fonem / $\mathrm{u} /$ menjadi $/ \mathrm{o} /$.

\section{DAFTAR PUSTAKA}


Alwasilah, A. Chaedar. 2005. Beberapa Madhab dan Dikotomi Teori Linguistil. Bandung: Angkasa

Chaer, Abdul. 2004. Linguistik Umum. Jakarta: Rineka Cipta.

Kridalaksana, Harimurti. 2009. Kamus Linguistik. Jakarta: Gramedia Pustaka Utama.

Moleong, Lexy J. 2009. Metodologi Penelitian Kualitatif. Ed. Revisi. Bandung: Remaja Rosdakarya.

Rahardi, Kunjana. 2001. Sosiolinguistik, Kode, dan Alih Kode. Yogyakarta: Pustaka Pelajar.

Sumarsonno dan Patana. 2004.

Sosiolinguistik. Jakarta: Sabda

Taha, Zainuddin. 2008. Gapura Bahasa Kumpulan Makalah Pilihan tentang Bahasa dan Pengajaran. Makassar: UNM. 